\title{
What Should We Do to Break Clinical Inertia in T2DM?
}

\author{
Takashi Ohoshi*1 and Kishio Nanjo ${ }^{2}$ \\ ${ }^{1}$ Department of Clinical Examination, Wakayama Rosai Hospital, Japan \\ ${ }^{2}$ Department of Internal Medicine, Wakayama Rosai Hospital, Japan
}

*Corresponding author: Takashi Ohoshi, Department of Clinical Examination, Wakayama Rosai Hospital, Japan

\begin{tabular}{ll}
\hline ARTICLE INFO & ABSTRACT \\
\hline
\end{tabular}

Received: 㸷 May 07, 2021

Keywords: T2DM; Clinical Inertia; Opened Medical Team; Patient-centered Care

Published: 慧 May 17, 2021

Citation: Takashi Ohoshi, Kishio Nanjo. What Should We Do to Break Clinical Inertia in T2DM?. Biomed J Sci \& Tech Res 35(5)-2021. BJSTR. MS.ID.005765.

\section{Opinion}

T2DM is a common disease progressed over the long duration of life. Because of lacking apparent symptoms and signs in many cases, interrelationship between patient and doctor becomes complicated.

\section{Process for Adjusting Blood Glucose}

Both a patient and his(her) doctor cannot know his(her) disease state before blood $\mathrm{A} 1 \mathrm{C}$ level is shown. His(her) prescription is determined by the $\mathrm{A} 1 \mathrm{C}$ level at visit and evaluated by the $\mathrm{A} 1 \mathrm{C}$ level of next visit. If patient reaches target $\mathrm{A} 1 \mathrm{C}$ level determined by clinical guideline and has no hypoglycemic symptoms and signs, his(her) prescription is proposed to continue, and if not, is proposed to adjust. This process is repeated continuously unless patient disrupts to visit for any reason.

\section{Origin of Clinical Inertia}

If patient disagrees proposal for his(her) lifestyle or adjustment of oral blood-glucose lowering drugs, GLP1 analogues, or insulin derivatives, his(her) doctor will try either to recommend it, or to propose other choice. Negotiation begins between patient and his(her) doctor, and then his(her) prescription is determined. If next visit $\mathrm{A} 1 \mathrm{C}$ level is not reached to target level, present prescription should be adjusted. But many patients do not like the change of prescription, especially when they want it by themselves. And the same prescription will be continued. From this time, clinical inertia [1] arises.

\section{What Should We Do?}

It is not impossible, but difficult, to break clinical inertia in the closed relationship between patient and his(her) doctor. Therefore, we should do organize medical team, which consists of patient him(her)self, his(her) doctor (general practitioner, diabetologist, if necessary, cardiologist, ophthalmologist, neurologist, nephrologist, dermatologist, orthopedic surgeon, etc.), diabetes educator (nurse practitioner, dietitian, pharmacist, physical therapist, and laboratory technician), other co-worker (clerk, medical social worker, care worker, public health nurse, etc.), and further his(her) family member(s). Opened relationship (Figure1) formed within this team would break clinical inertia.

\section{Patient-Centered Care}

If harmonized relationship, as had Steno-2 Study [2] shown, has developed, the medical team could provide patient-centered care [3] in T2DM. 


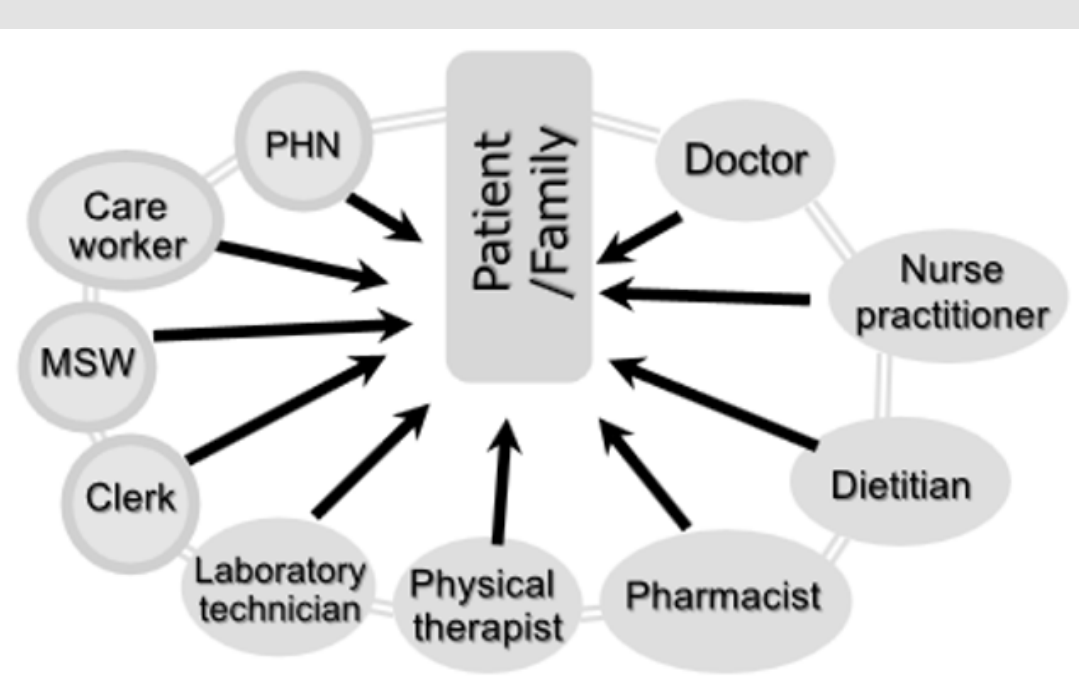

Figure 1: Opened Medical Team: Nurse practitioner, dietitian, pharmacist, physical therapist, and laboratory technician belong to diabetes educator.

\section{References}

1. Khunti K, Davies MJ (2017) Clinical inertia-Time to reappraise the terminology? Primary Care Diabetes 11(2): 105-106.

ISSN: 2574-1241

DOI: 10.26717 /BJSTR.2021.35.005765

Takashi Ohoshi. Biomed J Sci \& Tech Res

(c) (i) This work is licensed under Creative

Submission Link: https://biomedres.us/submit-manuscript.php
2. Gæde P, Vedel P, Larsen N, Jensen GVH, Parving HH, et al. (2003) Multifactorial Intervention and Cardiovascular Disease in Patients with Type2 Diabetes. N Engl J Med 348(5): 383-393.

3. (2017) NEJM Catalyst. What is Patient-Centered Care?

$\begin{array}{ll}\text { BIOMEDICAL } & \text { Assets of Publishing with us } \\ \text { RESEARCHES } & \text { - Global archiving of articles } \\ \text { - Immediate, unrestricted online access }\end{array}$

